\title{
Deteksi transmisi virus dengue pada nyamuk wild Aedes Aegypti betina di Kota Manado
}

\author{
${ }^{1}$ Grace Trovancia \\ ${ }^{2}$ Angle Sorisi \\ ${ }^{2}$ Josef S. B. Tuda
}

\author{
${ }^{1}$ Kandidat Skripsi Fakultas Kedokteran Universitas Sam Ratulangi Manado \\ ${ }^{2}$ Bagian Parasitologi Klinik Fakultas Kedokteran Universitas Sam Ratulangi Manado \\ Email: getrovancia@gmail.com
}

\begin{abstract}
Dengue hemorrhagic fever is an acute disease with clinical manifestations of hemorrhage caused by dengue virus infection. Manado is endemic dengue. Dengue virus has the ability to maintain its existence in nature through horizontal and vertical transmission. There are several ways to detect the dengue virus by Reverse Transcription-Polymerase Chain Reaction (RT-PCR) and immunohistochemistry Streptavidin Biotin Peroxidase Complex (ISBPC). This research aims to determine the wild Aedes aegypti population in Manado and to detect dengue virus in wild mosquito Aedes aegypti by ISBPC methods. This was a descriptive survey study with a cross sectional design to describe the transmission of dengue virus in wild mosquito Aedes aegypti in the city of Manado. The results showed that there were 5 wild Aedes aegypti mosquitoes positive for dengue virus, and 36 wild Aedes aegypti mosquitoes negative containing dengue virus. Conclusion: Of the 41 samples immunohistochemistry tested, 5 samples showed dengue virus transmission in wild mosquito Aedes aegypti in Manado which is a positive possibility of horizontal transmission.
\end{abstract}

Keywords: detection of dengue virus, transmission, wild Aedes aegypti, Manado.

\begin{abstract}
Abstrak: Demam berdarah dengue adalah suatu penyakit akut dengan manifestasi klinis perdarahan yang disebabkan oleh infeksi virus dengue. Manado merupakan daerah endemis demam berdarah. Virus dengue memiliki kemampuan untuk mempertahankan keberadaannya di alam melalui transmisi horizontal dan vertikal. Ada beberapa cara untuk mendeteksi virus dengue yaitu Reverse Transcription-Polymerase Chain Reaction (RT-PCR) dan imunohistokimia Streptavidin Biotin Peroxidase Complex (SBPC). Penelitian ini bertujuan untuk mengetahui populasi nyamuk wild Aedes aegypti di Kota Manado dan mendeteksi virus dengue pada nyamuk wild Aedes aegypti dewasa menggunakan metode imunohistokimia streptavidin biotin peroxidase complex (ISBPC). Jenis penelitian ialah survei deskriptif dengan desain potong lintang untuk mengetahui gambaran transmisi virus dengue pada nyamuk wild Aedes aegypti betina di Kota Manado. Hasil pene;itian mendapatkan 5 nyamuk wild Aedes aegypti positif mengandung virus dengue, dan 36 nyamuk wild Aedes aegypti negatif mengandung virus dengue. Simpulan: Berdasarkan hasil penelitian dapat disimpulkan bahwa dari 41 sampel yang telah diuji imunohistokimia, 5 sampel gambaran transmisi virus dengue pada nyamuk wild Aedes aegypti betina di Kota Manado yang kemungkinan transmisi horizontal adalah positif.
\end{abstract}

Kata kunci: deteksi virus dengue, transmisi, wild Aedes aegypti, Manado.

Demam berdarah dengue adalah suatu penyakit yang disebabkan oleh infeksi virus dengue. Demam berdarah dengue adalah penyakit akut dengan manifestasi klinis perdarahan yang menimbulkan syok yang berujung kematian. Demam berdarah 
dengue disebabkan oleh salah satu dari empat serotipe virus dari genus Flavivirus, famili Flaviviridae. ${ }^{1}$

Nyamuk Aedes aegypti merupakan pembawa utama (primary vector) dan Aedes albopictus merupakan vektor sekunder (secondary vector) dari Demam Berdarah Dengue. ${ }^{2}$ Seluruh wilayah di Indonesia mempunyai risiko untuk terjangkit penyakit demam berdarah dengue, karena nyamuk Aedes aegypti dan Aedes albopictus terdapat hampir di seluruh daerah di Indonesia. Penularannya telah tersebar luas di daerah perumahan maupun tempat-tempat umum. ${ }^{1}$

Demam Berdarah Dengue merupakan salah satu masalah utama kesehatan masyarakat di Indonesia. Setiap 5 tahun terjadi Kejadian Luar Biasa (KLB) DBD, bahkan ada beberapa kota terjadi KLB setiap tahun. Di Provinsi Sulawesi Utara, penyakit demam berdarah dengue pertama kali ditemukan di Manado pada tahun 1972, kemudian menyebar ke berbagai daerah. Angka insidennya masih sangat tinggi dalam beberapa tahun terakhir ini dan perkembangannya sangat fluktuatif. ${ }^{3}$ Manado merupakan salah satu daerah endemis demam berdarah. menurut data pemerintah 3 tahun terakhir mengenai jumlah kasus demam berdarah yang terjadi di Manado, demam berdarah selalu terjadi di kota Manado setiap tahunnya. Angka insidennya pun masih tinggi, pada tahun 2013 terjadi 410 jumlah kasus demam berdarah, tahun 2014 terjadi 517 kasus, dan 2015 terjadi 446 kasus. $^{3}$

Dibandingkan dengan nyamuknyamuk lain Aedes aegypti memiliki ukuran lebih kecil. Nyamuk Aedes aegypti memiliki ciri-ciri warna dasar hitam dengan bintik-bintik putih pada bagian badan, kaki, dan sayapnya, di bagian kepala terdapat garis putih berbentuk seperti kecapi. ${ }^{4}$

Pada siklus hidupnya nyamuk Aedes aegypti melewati 4 stadium yaitu telur, larva, pupa, dan dewasa. ${ }^{5}$ Tempat perindukan nyamuk Aedes aegypti di lingkungan yang lembab, terdapat genangan air di dalam maupun di luar rumah, dan curah hujan tinggi. ${ }^{6}$
Secara teoritis, nyamuk Aedes aegypti berkembang biak pada air bersih yang tidak bersentuhan dengan tanah. Namun perilaku nyamuk Aedes aegypti mulai berubah, jika sebelumnya nyamuk Aedes aegypti hanya suka berada di air bersih dan tidak bersentuhan langsung dengan tanah, sekarang nyamuk ini bisa tinggal di air yang tercemar. ${ }^{7}$

Virus dengue memiliki kemampuan untuk mempertahankan keberadaannya di alam melalui dua mekanisme yaitu transmisi horizontal dari manusia pembawa virus dengue ke nyamuk vektor Aedes aegypti, dan dengan transmisi vertikal (transovarial) yaitu dari nyamuk betina infektif ke generasi berikutnya. ${ }^{5}$

Masa inkubasi virus dengue dalam manusia (inkubasi intrinsik) berkisar antara 3 sampai 14 hari sebelum gejala muncul, gejala klinis rata-rata muncul pada hari keempat sampai hari ketujuh, sedangkan masa inkubasi ekstrinsik (di dalam tubuh nyamuk) berlangsung sekitar 8-10 hari. ${ }^{8}$

Manifestasi klinis mulai dari infeksi tanpa gejala demam, demam berdarah dengue, ditandai dengan demam tinggi terus menerus selama 2-7 hari; pendarahan diathesis seperti uji tourniquet positif, trombositopenia dengan jumlah trombosit $\leq$ $100 \times$ 109/L dan kebocoran plasma akibat peningkatan permeabilitas pembuluh. ${ }^{8}$

Terdapat beberapa cara untuk mendeteksi virus dengue yang terus dikembangkan diantaranya, antara lain Reverse Transcription-Polymerase Chain Reaction (RT-PCR) dan imunohistokimia Streptavidin Biotin Peroxidase Complex (SBPC). ${ }^{9}$

Pada prinsipnya metode imunohistokimia adalah perpaduan antara reaksi imunologi dan kimiawi, di mana reaksi imunologi ditandai dengan adanya reaksi antara antigen dengan antibodi sedangkan reaksi kimiawi ditandai dengan adanya reaksi antara enzym dengan substratnya. ${ }^{10}$

\section{METODE PENELITIAN}

Jenis penelitian ini ialah survei deskriptif yaitu untuk mengetahui gambaran transmisi virus dengue pada 
nyamuk`wild Aedes aegypti betina di Kota Manado. Penelitian ini dilaksanakan pada bulan Oktober - Desember 2016. Nyamuk wild Aedes aegypti betina yang memenuhi kriteria inklsi dan eksklusi. Deteksi virus dengue menggunakan imunohistokimia Streptavidin Biotin Peroxidase Complex (SBPC).

\section{HASIL PENELITIAN}

Berdasarkan hasil penangkapan nyamuk yang tertangkap ada 3 jenis nyamuk yang tertangkap, yaitu Aedes aegypti, Aedes albopictus, dan culex. Penangkapan dilakukan dengan 2 cara yaitu human bait dan sweeping, penangkapan yang dilakukan tidak hanya didalam ruangan namun juga diluar ruangan.

Tabel 1. Data nyamuk yang di tangkap di Kota Manado

\begin{tabular}{ccccc}
\hline Daerah & Jam & \multicolumn{3}{c}{ Jumlah Nyamuk } \\
\cline { 3 - 5 } & & $\begin{array}{c}\text { Aedes } \\
\text { aegypti }\end{array}$ & $\begin{array}{c}\text { Aedes } \\
\text { albopictus }\end{array}$ & Culex \\
\hline Malalayang I & $14: 00$ & 16 & & 2 \\
Winangun II & $18: 00$ & 3 & & 1 \\
Winangun II & $16: 00$ & 6 & & \\
Malalayang II & $10: 00$ & 4 & & \\
Malalayang II & $9: 00$ & 22 & 5 & \\
$\quad$ Sario & $10: 20$ & & 1 & \\
Malalayang I & $9: 00$ & 14 & & \\
\hline
\end{tabular}

Tabel 2. Data sekunder hasil uji presipitasi pakan darah wild Aedes aegypti betina

\begin{tabular}{ccc}
\hline Lokasi & $\begin{array}{c}\text { Jumlah } \\
\text { sampel }\end{array}$ & $\begin{array}{c}\text { Positif pakan } \\
\text { darah }\end{array}$ \\
\hline Jalan Sea & 9 & 9 \\
Winangun II & 3 & 3 \\
Winangun II & 3 & 2 \\
Malalayang II & 2 & 2 \\
Malalayang II & 13 & 13 \\
Malalayang I & 13 & 13 \\
\hline
\end{tabular}

Hasil tes Imunohistokimia pada wild Aedes aegypti di Kota Manado

Dari hasil penangkapan yang dilakukan menunjukkan bahwa nyamuk wild Aedes aegypti di kota Manado positif uji presipitasi pakan darah.

Setelah mendapatkan hasil uji presipitasi, sampel yang positif diuji kembali menggunakan metode imunohistokimia (Tabel 3).

Tabel 3. Data hasil tes imunohistokimia wild Aedes aegypti betina

\begin{tabular}{lcccc}
\hline \multirow{2}{*}{ Daerah } & \multicolumn{2}{c}{ Aedes aegypti } & \multicolumn{2}{c}{ IHC } \\
\cline { 2 - 5 } & Jantan & Betina & + & - \\
\hline Malalayang I & 7 & 9 & 4 & 5 \\
Winangun II & 3 & 3 & & 3 \\
Winangun II & 3 & 3 & 1 & 2 \\
Malalayang II & 2 & 2 & & 2 \\
Malalayang II & 9 & 13 & & 13 \\
Malalayang I & 3 & 11 & & 11 \\
\hline
\end{tabular}

Gambar preparat head squash hasil tes imunohistokimia.

Preparat yang telah di tes imunohistokimia akan menunjukan hasil berwarna coklat bila positif dan ungu apabila negatif.
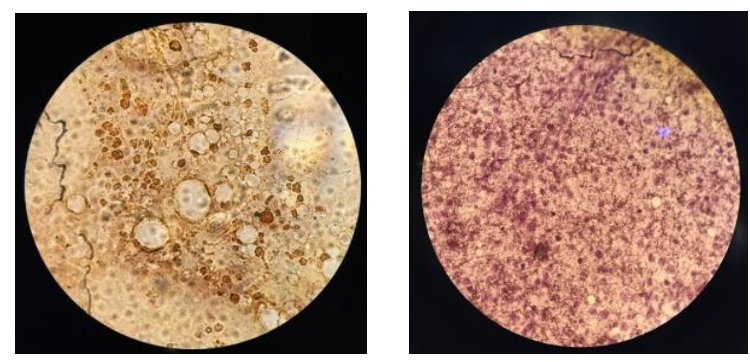

Gambar 6. A. Hasil tes IHC positif ; B, Hasil tes IHC negatif

\section{BAHASAN}

Pada penelitian yang telah dilakukan pada bulan Oktober hingga bulan Desember 2016 mengenai deteksi transmisi horizontal virus dengue pada nyamuk wild Aedes aegypti di kota Manado didapatkan dari seluruh nyamuk yang di tangkap 65 nyamuk wild Aedes aegypti, 6 nyamuk Aedes albopictus, dan 3 nyamuk culex spp. Dari 65 nyamuk wild Aedes aegypti 41 nyamuk betina. Penangkapan di lakukan dengan 2 cara yaitu cara human bait dan sweeping, penelitian juga dilakukan di dalam ruangan dan di luar ruangan.

Pada transmisi horizontal nyamuk yang menjadi sampel harus sudah positif uji presipitasi pakan darah, karena 
transmisi horizontal akan terjadi saat nyamuk Aedes aegypti yang tidak terinfeksi virus dengue menghisap darah manusia yang telah terinfeksi virus dengue. Pada tabel 3 didapatkan 40 nyamuk betina positif tes presipitasi pakan darah. Tes presipitasi dilakukan untuk mengetahui ada atau tidaknya darah di lambung nyamuk, yang pada penelitian ini menjadi dasar terjadinya transmisi horizontal.

Nyamuk yang positif tes presipitasi pakan darah akan dilakukan uji imunohistokimia, Uji Imunohistokimia merupakan perpaduan antara reaksi imunologi dan kimiawi, di mana reaksi imunologi ditandai dengan adanya reaksi antara antigen dengan antibodi sedangkan reaksi kimiawi ditandai dengan adanya reaksi antara enzym dengan substratnya. Dasar utama reaksi imunohistokimia (SBPC) yaitu ikatan yang sangat kuat antara streptavidin dengan biotin. Ketika kadar antibodi sekunder yang dilabel biotin yang terikat lebih banyak, hal itu dapat meningkatkan kemungkinan untuk mengikat konjugat strepatvidin yang dilabel enzim horseradish peroksidase. Ketika enzim peroksidase mengkatalisis subtrat hidrogen peroksidase, kromogen diamino-benzidine (DAB) akan diubah menjadi deposit warna coklat yang menandakan adanya antigen virus dengue. Apabila saat pencucian dengan phosphate buffered saline (PBS) antibodi primer dan sekunder hanyut atau terbuang, dan saat diinkubasi selama tiga menit terjadi penyerapan oleh jaringan/sel menunjukan warna biru atau ungu, maka hasil antigen negatif. Setelah dilakukan uji imunohistokimia didapatkan hasil 5 nyamuk wild Aedes aegypti positif mengandung virus dengue, dan 36 nyamuk wild Aedes aegypti lainnnya negatif mengandung virus dengue. Menurut hasil penelitian yang telah dilakukan sebelumnya di Malalayang tahun 2014 tentang indeks transmisi transovarial nyamuk Aedes aegypti dan Aedes albopictus, peneliti mendapatkan hasil yang sejalan yaitu hasil positif pada tes imunohistokimia pada preparat head squash nyamuk.
Dengan adanya hasil positif yang didapatkan dari penelitian ini maka hal ini menunjukan bahwa terjadi tranmisi virus dengue pada nyamuk wild Aedes aegypti betina di kota Manado yang kemungkinan merupakan transmisi horizontal.

Keterbatasan penelitian yang dialami peneliti berupa kurangnya sumber mengenai transmisi horizontal karena lebih banyaknya penelitian yang membahas transmisi transovarial dibanding horizontal. Bias pada penelitian ini disebabkan oleh karena dapat terjadinya tumpang tindih hasil yang memungkinkan hasil positif uji imunohistokimia bukan merupakan transmisi horizontal melainkan transmisi transovarial.

\section{SIMPULAN}

Berdasarkan hasil penelitian yang dilakukan dapat disimpulkan bahwa dari 41 sampel yang telah diuji imunohistokimia, 5 sampel gambaran transmisi virus dengue pada nyamuk wild Aedes aegypti betina di Kota Manado yang kemungkinan transmisi horizontal adalah positif.

\section{SARAN}

Diperlukan penelitian selanjutnya dengan teknik penilaian lain yang dapat lebih spesifik membuktikan bahwa transmisi yang terjadi pasti merupakan transmisi horizontal bukan transovarial.

Bagi masyarakat luas dihimbau untuk dapat memutus rantai siklus hidup nyamuk Aedes aegypti karena dalam transmisi horizontal dan transovarial peran vektor sangat berpengaruh.

\section{DAFTAR PUSTAKA}

1. Sukohar A. Demam Berdarah Dengue (DBD). Fakultas Kedokteran Universitas Lampung. 2014. Volume 2.h.2-3,

2. Kuryanti MR, Hadinegoro S R. Perubahan Epidemiologi Demam Berdarah Dengue di Indonesia. Departemen Ilmu Kesehatan Anak Rumah Sakit Dr. Cipto Mangunkusumo FKUI Jakarta. 2009. Volume 10 Nomor 6.p 425.

3. Pongsilurang CM, Sapulete M R, Kaunang 
W P J. Pemetaan Kasus Demam Berdarah Dengue di Kota Manado. Ilmu Kedokteran Komunitas Fakultas Kedokteran Universitas Sam Ratulangi. 2015. Volume 3 Nomor 2.

4. Florida Medical Entomology Laboratory. Photographic Guide to Common Mosquitoes of Florida. University of Florida.p. 16

5. Soedarto. Demam Berdarah Dengue. Sagung Seto. Jakarta: 2012.

6. Gama AT, Betty FR. Analisis Faktor Risiko Kejadian Demam Berdarah Dengue di Desa Mojongsongo Kabupaten Boyolali. Eksplanasi. Volume 5 Nomor 2. 2010.

7. Baharudin A, Rahman. Karakteristik Breeding Places dan Pertumbuhan Larva Aedes Aegypti. Departemen Kesehatan Lingkungan Fakultas Kesehatan Masyarakat Universitas Muslim Indonesia. Volume 1 Nomor 2. 2015

8. Candra A. Demam Berdarah Dengue: Epidemiologi, Patogenesis, dan Faktor Resiko Penularan. Aspirator. 2010. Volume 2 Nomor 2.

9. Sorisi AMH. Tranmisi Transovarial Virus Dengue Pada Nyamuk Aedes spp. Jurnal Biomedik (JBM). Volume 5 Nomor 1. 2013.p.26-31.

10. Widiarti, Boewono $\mathrm{D} T$, Widyastuti U. Deteksi Antigen Virus Dengue pada Progeni Vektor Demam Berdarah dengan Metode Imunohistokimia. Balai Besar Penelitian dan Pengembangan Vektor dan Reservoir Penyakit Salatiga. Volume 37 Nomor 3. 2009.p. $126-136$.

11.Kuryanti M R, Hadinegoro S R. Perubahan Epidemiologi Demam Berdarah Dengue di Indonesia. Departemen Ilmu Kesehatan Anak Rumah Sakit Dr. Cipto Mangunkusumo FKUI Jakarta. 2009. Volume 10 Nomor 6.p
425 .

12.Pondaag K, Tarumingkeng A, Umboh $\mathrm{J}$. Hubungan Antara Tindakan Pencegahan dengan Kejadian Demam Berdarah Dengue di Kecamatan Malalayang Kota Manado. [Fakultas Kesehatan Masyarakat Universitas Sam Ratulangi].

13.Pongsilurang CM, Sapulete MR, Kaunang WPJ. Pemetaan Kasus Demam Berdarah Dengue di Kota Manado. Ilmu Kedokteran Komunitas Fakultas Kedokteran Universitas Sam Ratulangi. 2015. Volume 3 Nomor 2.

14.Gama A T, Betty F R. Analisis Faktor Risiko Kejadian Demam Berdarah Dengue di Desa Mojongsongo Kabupaten Boyolali. Eksplanasi. Volume 5 Nomor 2. 2010.p.4.

15.WHO. Dengue: Guidlines for Diagnosis, Treatment, Prevention and Control. New Edition. Geneva: World Health Organization;2009.

16.Soegijanto S. Patogenesa dan Perubahan Patofisiologi Infeksi Virus Dengue. www.pediatrikcom/buletin/20060220 - 8ma2gi-buletindoc; 2002 [cited 2010]

17.Frans EH. Patogenesis Infeksi Virus Dengue. Fakultas Kedokteran Universitas Wijaya Kusuma Surabaya. 2010.

18.Perhimpunan Dokter Spesialis Penyakit Dalam Indonesia. Buku Ajar Ilmu Penyakit Dalam. Interna Publishing;2014.p.541-548.

19.Florida Medical Entomology Laboratory. Photographic Guide to Common Mosquitoes of Florida. University of Florida.p.16

20.I Kartika. Aedes aegypti Sebagai Vektor Demam Berdarah Dengue. Fakultas Kedokteran Universitas Wijaya Kusuma Surabaya. 